\title{
Managing national security interests amidst military major powers' military engagements
}

\author{
Kosh Raj Koirala
}

\begin{abstract}
Existing literatures on the strategic competition between India, China and the US have largely focused on general patterns and trends of their cooperation and engagements in Nepal, including on how China has made its forays in Nepal with its assertive foreign policy overtures since 2008. What has been overlooked, however, is how these three countries are quietly competing with each other to enhance their engagement with the national army. The growing competition among these countries is likely to pose serious challenge to the national army as an institution to exercise its strategic autonomy in its decision making process if some cautions are not exercised in advance. This paper highlights on competing and conflicting interests of major powers to enhance their engagements with the national army in Nepal, and the ways to overcome potential challenges, such military engagements may entail in the future. It also offers a context of the discussion with a brief overview of changing strategic environment in the Asia Pacific in the past 10 years and how Nepal has transformed from a backwater to strategic epicenter for major powers.
\end{abstract}

Keywords: military engagement, national security, Indo-Pacific strategy, geopolitical competition, major powers, competing and conflicting interests

\section{Introduction}

Because of its geographic location, Nepal maintains geostrategic and geopolitical importance for its immediate neighbors India and China - as well as the world major powers. The importance of Nepal in the geopolitical and geostrategic landscape has only increased further in recent years, with the Rise of China and its assertive foreign policy overtures in its immediate neighborhood and beyond. While the US appears to be responding to the growing Chinese assertiveness in the entire Asia Pacific region, including Nepal under its broader cooperation framework of Indo-Pacific Strategy, India surges to influence Nepal in all spheres for the past several decades. Likewise, the southern neighbor maneuvers both its soft and hard power resources at its disposal to maintain its influence in this Himalayan nation. As the peace process that paved the way for the then underground Maoist rebels to join mainstream politics in Nepal remains still incomplete and major political forces in the country are stuck in internal squabbles. In such a fragile political situation, Nepal's immediate neighbors, India and China along with the US are persistently heightening their engagements with the national army in an apparent bid to secure their vital interests in Nepal. But this appears to have given rise to a quiet competition among China, India and the US in their military engagements, transforming Nepal from a backwater to a 
strategic epicenter in the changed strategic landscape.

\section{Changing strategic environment in Asia Pacific}

The rise of China as an economic superpower along with its massive military modernization after 2008 is one of the main factors behind the changed strategic environment in the AsiaPacific. While all other major economies in the West were heavily affected by the economic recession that started from the US, China became a strong exception to this global financial crisis that started in 2008 (Morrison, 2009, p. 3). This boosted confidence of China that experienced centuries of humiliation at the hands of colonial powers to increase its influence through the use of hard and soft power resources. Despite its perennial struggle to recover from the financial crisis, the US was then forced to respond to the growing Chinese assertiveness in various parts of the Asia Pacific, including South China Sea. Then US President Barack Obama unveiled 'Pivot to Asia' or 'Rebalancing Asia' in 2012 to put additional focus on the Asia Pacific region in view of China's assertive foreign policy overtures. The purpose of this strategy was to deepen U.S. credibility in the region at a time of fiscal constraint (Manyin. et. al., 2012, p. 1) that the US was facing at the time as a result of economic recession. The key areas of actions of this strategy included "strengthening bilateral security alliances; deepening working relationships with emerging powers, including China; engaging with regional multilateral institutions; expanding trade and investment; forging a broad-based military presence; and advancing democracy and human rights" (Clinton, 2011).
With President Donald Trump assuming his office in 2017, the US unveiled an Indo Pacific Strategy with the primary objective to ensure "Free and Open Indo-Pacific" (FOIP), apparently to challenge China's claim over entire South China Sea. According to the Pentagon's report published in June last year, the Indo-Pacific Strategy revolves around simultaneous enhancement of long -standing objectives on economic engagement, security cooperation and strengthened governance - a balance of priorities that aligns with the approaches of key partners like Japan, Australia and India. The US unveiled several other initiatives such as Indo-Pacific Security Initiatives in which it allocated \$300 million to "reinforce security cooperation" in the Indo-Pacific region (Scott, 2018. p. 36). Toward the end of December, 2018, the US also came up with Asia Reassurance Initiative Act to assure its partners and allies that US was still committed to help them in view of rising Chinese influence. This Act also formally recognized India as its major defense partner, paving way for New Delhi to obtain state of the art technology from Washington to achieve self-sufficiency in defense manufacturing (Chaudhary, 2018).

The US's proactive presence in the Asia Pacific region along with military partnership with different major powers is widely perceived as an attempt to contain China. Beijing under Xi Jinping in particular also began responding to the US overtures through increased engagements with countries in its neighborhood and beyond in the following years. Chinese foreign policy after 2008 witnessed changes mainly in three fronts that include enhanced regional cooperation, deviation from non-interference policy in internal affairs of other countries, and increased assertiveness (Qi et. al., 2013). 
China has been increasingly influencing in India's small neighbors through various measures: grant assistance, investment in major infrastructure projects, such as hydropower plants and port city development, scholarship to students, military aid as well as training to security personnel, military exchange, and high level visits (Curtis, 2016). Formulation of new periphery diplomacy, setting the goal of building two "Silk Roads" under Belt and Road Initiatives (BRI), increasing great power responsibility including through the participation in the UN peacekeeping and, adopting more flexible pragmatism in its foreign policy, combining a "carrot and stick" approach, (Yizhou, 2014) are some of President Xi's foreign policy innovations.

The strategic competitions between the US and China in the Asia Pacific region in recent years have brought profound changes in Nepal's geopolitical and geostrategic landscape, prompting Nepal's immediate neighbors India and the US to increase their assertiveness. Nepal's southern neighbor has been continuously influencing Nepal in its politics and military since the 1950s, while the US also had its modest presence in Nepal, especially after the Tibetan uprising in 1959. Further, the US continues its organized engagements after an exodus of a large number of Tibetans to Nepal and India after their failed uprising against China's takeover of Tibet. Although the mass exodus of Tibetan protestors and the rebellion against the Chinese presence in Tibet from Nepali soil heightened the Chinese concern, the interaction between the two countries were confined largely to the Chinese economic and technical assistance to a few key pride projects and the occasional exchange of high level political visits between the two countries until 2008. China's policy of limited interaction with Nepal also witnessed a major political change that brought Maoist rebels into mainstream politics, and subsequently abolished the 240-year old institution of monarchy in 2008.

China's foreign policy departure coincided with anti-China protests of the Tibetan refugees in Kathmandu streets just ahead of the Beijing Olympics 2008, and India's strategic alignment with the US. China's increased engagements in Nepal can be seen mainly after the fall of monarchy, which many scholars in Nepal argue that Beijing considered a reliable political force to protect its vital interests in Nepal in 2008. Nepal was then undergoing a critical political transition when the United Nations Mission in Nepal was initiating to facilitate the peace process. Although the Chinese leadership never reacted explicitly in public, they had a concern that western powers could incite anti-China elements in Nepal. During his meeting with Prime Minister Khadga Prasad Oli in Kathmandu in October 2019, Chinese President Xi Jinping did not hesitate to say that some western forces were using Nepal to destabilize parts of China [Reuters, 2019]. All of these events reflect Nepal's transformation itself from backwater to a strategic epicenter for major powers that have linked their strategic interests in Nepal.

\section{Military engagements of major powers}

As the peace process that started in 2006 prolonged for years amid deepening political uncertainty and the country's main political forces were caught up in internal wrangles, major international powers-- mainly China, the US and India -- seem to have increased their engagements with security agencies, mainly the Nepali Army (NA). The NA 
and Indian Army have a unique tradition to recognize each other's army chief as their honorary chief. There is a special arrangement in place with Indian Army that allows the NA to buy arms from India in 60 percent of their cost, while remaining 40 percent cost of such arms is borne by Indian government under grant. Nepal has been obtaining military hardware including arms and ammunitions, vehicles and training opportunities from India. Since Nepal and India share open border regime, the primary interests of India to cultivate relations with the NA is to address its traditional security concerns and check the growing influence of the US and China in Nepal. The position maintained by India against the decision of then Prime Minister Pushpa Kamal Dahal in 2009 to sack then Army Chief Rookmangud Katawal in Nepal exposes the Indian interest in the NA (IANS, 2009).

The Chinese engagement with the NA also unfolds a sharp rise, mainly after the political change in Nepal followed by the abolition of the 240-year old institution of monarchy in 2008. China, which initially provided non-lethal military logistics to NA, now has expressed willingness to extend any supports that the NA asks for and the volume of military aid China has been providing to the army has only increased further in recent years. For instance, China provided medical equipment worth Rs 800 million to the NA in the year 2072 BS. The army also received Rs 9.7 million worth mobile field hospital and Rs 1.31 billion worth Armored Personnel Carriers, tents and communication equipment that are primarily used in peacekeeping operations in the following year and vehicles, radio sets and water tankers, among others, worth Rs 3.80 billion in the year 2074 BS. During the visit of Deputy Prime Minister and
Defense Minister Ishwar Pokharel in October, 2018, Beijing further agreed to provide Rs 2.47 billion worth military logistics to the army (Pandey, 2020).

On the one hand, China has clearly expressed in its Defense White Paper released in 2019 that it aims to build close military ties with neighboring countries with exchange of visits of chief of army and through enhanced military cooperation (State Council Information Office of the People's Republic of China, 2019. p. 33). While China has also significantly increased training opportunities to the NA officials, all Defense Ministers and top leadership of army are regularly making visit to the northern neighbor after 2008. This seems to have been made not at Nepal's will alone, but in the interest of China since Beijing has been deepening military engagements with all small neighbors of India to increase its influence (Chapagain, 2019). The fact that China extended Rs 12 billion worth military assistances as compared to Rs 5 billion worth military assistance provided by the US in the past five years to the NA (Pandey, 2020) speaks how much importance Beijing has attached to Nepal's national army to meet its security interests.

On the one hand, the US has significantly increased its engagements with Nepal's national army in line with its foreign policy to give priority to the Asia Pacific Region in response to China's assertive foreign policy in the region. While Obama administration began to focus more on Asia Pacific region under Pivot Asia or Asia Rebalancing policy, Trump administration continued with similar policy with Indo-Pacific Strategy that primarily seeks to maintain its influence and reassure its allies and partners that US is there in the times of need. The NA has 
been working together with the US Army in six different areas including joint military exercises and capacity enhancement trainings (Koirala, 2019). As a part of its Indo-Pacific Strategy, the US has increased its assistance and engagements for what it describes to help Nepal to defend its sovereignty and counter any foreign aggression. A report of IndoPacific Strategy released by US Department of Defense in June, 2019 states that US seeks to expand defense relations with Nepal focused on HA/DR, peacekeeping operations, defense professionalization, ground force capacity and counter-terrorism. The growing defense partnership can be seen in the establishment of the US Army Pacificled Land Forces Talks - senior most military dialogue of the US -- held in June 2018 (p.36). While the US is working to operationalize Major Defense Partnership with India, it is pursuing emerging military partnership with four South Asian nations including Nepal (p. 21). Most recently, the US handed over two M28 sky trucks to the NA, while two others are in the pipeline as a part of its US\$ 15 million grant assistance to the army (US Embassy in Nepal, 2019).

Besides, the US has also launched a Global Peace Operation Initiatives with a view to promote military partnership with various 14 countries including Nepal in Asia Pacific region. Discussions are underway at the level of government between the two countries to include Nepal in State Partnership Program, which works in partnership with the army in the field of humanitarian service and disaster management involving US National Guards. Among other things, the US has shown interests in providing technical and financial assistance to Nepali Army to establish Defense University. The military assistance US provided to Nepal in the last five years amounts to Rs 5.23 billion. The fact that US Secretary of State Mike Pompeo during his meeting with Foreign Minister Pradeep Gyawali in Washington in December 2018 solicited Nepal's 'central role' in the IndoPacific Strategy speaks in volume as to how much importance US attaches to Nepal (Koirala, 2018).

\section{Competing and conflicting security interests}

There is no denying that the support the national army has been receiving from India, China and the US has helped the national army in a number of ways. But it would be wise on our part to exercise some caution as these assistances do not come without any strings attached. We should be cautious of the fact that the major powers deepening their engagements with the army. At times, conflicting concerns in Nepal safeguard those interests by bringing army--a reliable force in the country-into their confidence. There is a general understanding among experts and scholars in Nepal that political instability and lack of consistency in the stances held by major political parties on crucial issues have made both neighbors as well as major outside powers increasingly look for national army to secure their vital interests. A section of scholars also argue that the growing bonhomie between ruling Nepal Communist Party (NCP) and Communist Party of China (CPC) have equally made India and the US apprehensive, giving them an imperative to further increase their engagement with the national army to maintain their influence (Kaphle, 2019).

One of the primary foreign policy objectives of India and the US in Nepal has been to strengthen democratic system in Nepal. 
This is reflected in the speeches of the top leaders of these countries. The ideological proximity that is seen between the NCP and the CPC in recent years, with CPC leaders landing in Kathmandu in September 2019 for orientation on Xi Jinping Thoughts to the ruling NCP leaders appears to have made them further apprehensive over the NCP's potential ideological shift (Giri, 2019). India considers Nepal as its traditional sphere of influence. The last thing, therefore, India wants is growing influence of China-- its strategic rival power in the region-- in Nepal. All the engagements of India in Nepal are aimed at offsetting growing influence of China, if not of the US. But as the influence of India has waned significantly in recent years, the US seems to have chipped in to play that role, given that these two countries share common interests to neutralize, if not offset the influence of China and use their leverage to avoid Nepal from deviating from the current democratic political course. Growing engagements of US with the army can also be seen in view of the fact that the US has increasingly started looking Nepal through its own lens - rather than through the lens of New Delhi -- in recent years in view of growing engagements of China. Highlevel visits of army and defense officials from both the US and China to Nepal in recent years invariably in every next month and their statements during their meetings with their Nepali counterparts and with the media persons reveal their competing and conflicting security and strategic interests in Nepal.

\section{Conclusion}

While diplomacy is the first line, the national army serves as the last line of national defense of any country. With the increasing volume of monetary as well as logistical aid that the army has been receiving from countries that have conflicting and competing strategic interests, the national army as an institution could face an insurmountable challenge to balance their interests and maintain strategic autonomy in the days ahead. The military assistances these three major powers have been extending to the NA are vitally important for promoting professionalization and enhancing work efficiency of the army personnel with availability of required logistics. But given their competing and conflicting interests, it is important to exercise some cautions. Both political and army leadership should make sure that any such support do not compromise the army's ability to take independent decisions that do not in any way jeopardize national security interests. The government should also allocate adequate defense budget to fulfill basic needs of army in order to gradually reduce dependency of army to foreign donors even to meet its requirements of basic logistics.

With the rise of China and its assertive foreign policy in recent years, the whole of Asia Pacific has become a strategic of strategic competition among major world powers. Given its unique geostrategic location between emerging economic and military superpowers -- China and India--, Nepal has also transformed into a strategic epicenter for major world powers in recent years. The growing interest of these major powers to deepen their engagements with the national army through various means is nothing but manifestation of their conflicting and competing strategic interests in Nepal. It is, therefore, important to set a Red Line on the part of the government and the army while receiving military assistances offered by any of these countries. These assistances should 
be in line with Nepal's principled foreign policy goal to have "Amity with all, Enmity with None." The army as an institution should be able to keep itself free from any foreign influence, so that it can exercise its strategic autonomy in decision making process and act in the best interests of Nepal and Nepali people.

\section{References}

Chapagain, K. (2019, July 1). Chinako gahirido sainya kutniti i.e. Deepening military diplomacy of China. Himal Khabar. Retrieved from: https://www.himalkhabar. com/news/13267

Chaudhary, D. R. (2018, July 12). US recognizes India as 'major defense partner' Economic Times. Retrieved from: https://economictimes.indiatimes. com/news/defence/us-recognises-india-asmajor-defence-partner/articleshow/52645652. cms?utm_source=contentofinterest\&utm medium $=$ text\&utm_campaign $=$ cppst

Clinton, H. (2011, October 11). America's Pacific century. foreign policy. Retrieved from: https://foreignpolicy. com/2011/10/11/americas-pacific-century/

Curtis, L. (2016, March 17) China's South Asia strategy. The heritage foundation. Retrieved from http://www.heritage. org/research/testimony/chinas-south-asiastrategy

Department of defense. 2019. IndoPacific strategy report: Preparedness, partnerships, and promoting a networked region. Retrieved from: https://media. defense.gov/2019/Jul/01/2002152311/-1/1/1/DEPARTMENT-OF-DEFENSE-INDOPACIFIC-STRATEGY-REPORT-2019.PDF
Giri, A. (2019, September 24). Training program on $\mathrm{Xi}$ Jinping thought raises concerns among opposition leaders. Kathmandu Post. Retrieved from: https://kathmandupost. com/national/2019/09/24/trainingprogramme-on-xi-jinping-thought-raisesconcern-among-opposition-leaders

IANS. (2009, April 26). India asks Nepal not to meddle with army. Hindustan Times. Retrieved from: https://www.hindustantimes.com/world/indiaasks-nepal-not-to-meddle-with-army/storyg18CfOiP0ME2bLB6aoR20O.html

Kaphle, P. (2019, December 8). Senama Kina Badhdaichha Shakti Rastrako Chaso i.e. Why are major powers increasing their interests in army? Naya Patrika. Retrieved from: https://www.nayapatrikadaily.com/newsdetails/30745/2019-12-08?fbclid=IwAR3zwE fHk2_8hQNpJO0d2ZT4NiBUSbeglZSKp9Dj YdPAKDlsxNDdryYLbJ4

Koirala, K. R. (2018, December 20). US seeks key role for Nepal in Indo-Pacific as China ups forays. Republica. Retrieved from: https://myrepublica.nagariknetwork. com/news/us-seeks-key-role-for-nepal-inindo-pacific-as-china-ups-forays/

Koirala, K. R. (2019, February 26). US seeks to further deepen military cooperation with Nepal. Republica. Retrieved from: https://myrepublica.nagariknetwork. com/news/visiting-us-defense-secy-felterseeks-to-further-deepen-military-cooperationwith-nepal/

Manyin, M. E. , Daggett, S., Dolven, B., Lawrence, S. V., Martin, M. F., O' Rourke, R. and Vaughn, B. (2012, March 28). Pivot to the Pacific? The Obama Administration's "Rebalancing" Toward Asia. Congressional Research Service. Retrieved from: https://fas. org/sgp/crs/natsec/R42448.pdf 
Morrison, W. M. (2009, June 3). China in the global financial crisis: Implications for the United States. Congressional Research Service. Retrieved from: https://www.searchnewworld. $\mathrm{com} / \mathrm{search} / \mathrm{search} 2$. artid $=$ rolbng $\& \mathrm{p}=$ China $\% 27 \mathrm{~s}+$ morale + was + boosted + after+the+economictrecession + did + not + hit + it + in +2008 \&subid $=004$

Reuters. (2019, October 13). China's Xi warns attempts to divide China will end in 'shattered bones'. Retrieved from: https://www.reuters. com/article/us-china-politics-xi/chinas-xiwarns-attempts-to-divide-china-will-end-inshuttered-bones-idUSKBN1WS07W

Scott, D. (2018). The "Indo-Pacific" in US strategy: Responding to power shift. Rising Powers Quarterly. 3 (2), pp. 19-43.

State Council Information Office of the People's Republic of China. (2019). China's national defense in the new era. Retrieved from: http://english.www.gov. cn/archive/whitepaper/201907/24/content WS5d3941ddc6d08408f502283d.html

US Embassy in Nepal. (2019, December 18). U.S. Hands Over Skytrucks to the Nepali Army. Retrieved from: https://np.usembassy. gov/hands-over-skytrucks/
Qi, C., Haenle, P., Cronin, P. \& Ratner, E. (2013, November 4). China's evolving foreign policy and implications for US-China relations. Carnegie Tsinghua. Retrieved from: http://carnegietsinghua.org/2013/11/04/chinas-evolving-foreign-policy-and-implicationsfor-u.s.-china-relations/gvud.

Pandey, J. (2020, January 2). Sainya sahayog America bhanda chinko badhi i.e. China tops US in military assistances. Kantipur. Retrieved from:https://ekantipur.com/news/2020/01/02/157 792881484031427.html?fbclid=IwAR1tjFSc1MnE8wEh3M1Qvf-AlwkFIVya8GIHyCfri4 RzLWWq6XgB5Iz43Y

Yizhou, W. (2014, March 21). China's new foreign policy: Transformations and challenges reflected in changing discourse. The Asan Forum. Retrieved from:http://www. theasanforum.org/chinas-new-foreign-policytransformations-and-challenges-reflected-inchanging-discourse 